Ryszard KOWALCZYK

Uniwersytet im. A. Mickiewicza, Poznań

\title{
Prasa lokalna - między misją a rynkiem
}

\begin{abstract}
Wstęp
W moim wystąpieniu zajmę się relacją, jaka istnieje między misją prasy lokalnej a rynkiem, na jakim ona występuje i funkcjonuje. Skutkiem tej relacji są czasami napięcia społeczne, a nawet konflikty. Misja i rynek są także pewnymi mniej lub bardziej ważnymi wartościami w praktyce prasy lokalnej, których znaczenie zależy od charakteru i typu instytucji wydawniczej. Te elementy zaś są definiowane głównie przez relacje z czytelnikami i rynkiem. W ostateczności mamy więc do czynienia ze zjawiskiem sprzężenia zwrotnego, które polega tutaj na wzajemnych oddziaływaniach misji i rynku. Ich rezultatem są określone zmiany, jakie zachodzą w obu tych obszarach. W konsekwencji oczekiwania rynku mają wpływ na zakres znaczeniowy pojęcia misji i odwrotnie.

Ważne w tym kontekście jest udzielenie odpowiedzi na pytanie: Jaki jest wpływ tych czynników na zachowanie prasy lokalnej? Pytamy się wówczas głównie o zakres tego wpływu oraz skutki, jakie wywiera. Mówiąc o zakresie wpływu, myślimy zazwyczaj o liczbie obszarów, jakie podlegają oddziaływaniu. Natomiast skutki są obserwowalne w zmianach, jakie zachodzą $w$ podmiocie i jego relacjach $\mathrm{z}$ otoczeniem.

Na pojęcie misji i rynku oddziałuje szereg czynników, które podlegały zmianom pod wpływem określonych wydarzeń. Stąd definiowanie misji i rynku nie może się obejść bez uwzględniania szerszego kontekstu. System prasowy jest przecież częścią systemów politycznego i gospodarczego i wraz z nimi ulega określonym przekształceniom ${ }^{1}$. Na definiowanie misji prasy ma więc ogromny wpływ system, w jakim ona funkcjonuje. Dlatego podczas analizy relacji między misją a rynkiem należy odnieść się do przeobrażeń, jakim podlegała prasa lokalna na przełomie lat 80 . i 90. Okres transformacji systemowej w zasadniczy sposób zmienił oto-

1 Por. B. Ociepka, Dla kogo telewizja?, Wrocław 2003, s. 23.
\end{abstract}


czenie, w jakim funkcjonowała prasa, a wraz z nim także samą prasę 2 . W jej rozwoju wyróżnia się trzy etapy, które są definiowane za pośrednictwem osobliwych czynników. Określają one w zasadzie cechy i charakter tych stadiów.

\section{Od elitarności do popularności}

Współczesna prasa lokalna, przeżywająca swój dynamiczny rozwój od początku lat $90 .^{3}$, przeszła w pierwszym okresie od stadium elitarności do stadium popularności. Etap elitarności charakteryzowały między innymi takie zjawiska, jak:

1) mała liczba tytułów i czytelników oraz niewielki nakład prasy lokalnej,

2) współistnienie dwóch systemów prasowych - legalnego i nielegalnego (prasa podziemna),

3) ograniczony zasięg kolportażu (często zawężony do niewielkiej liczby zurbanizowanych i stosunkowo dużych skupisk ludności miejskiej),

4) sprzeczność interesów nadawców i odbiorców, która polegała na tym, że pierwsi traktowali prasę głównie jako narzędzie oddziaływania propagandowego na społeczeństwo i agitacji; drudzy zaś oczekiwali od prasy zaspokajania ich potrzeb ogólnoinformacyjnych, poznawczych i kontrolnych,

5) niedostosowanie zawartości prasy lokalnej do rzeczywistych potrzeb czytelników, których interesowały głównie informacje dotyczące najbliższego otoczenia.

Wśród czynników ograniczających rozwój prasy lokalnej w tym okresie wymienia się między innymi:

2 Por. Polskie media w okresie przemian, pod red. J. Olędzkiego, Warszawa 1991; Transformacja prasy w Polsce (1989-1992), pod red. A. Słomkowskiej, Warszawa 1992; Kontrowersje wokót transformacji prasy polskiej (1989-1992), pod red. A. Słomkowskiej, Warszawa 1993; Media i dziennikarstwo w Polsce (1989-1995), pod red. G. G. Koppera, I. Rutkiewicza, K. Schliep, Kraków 1996; Środki masowej informacji w Polsce po likwidacji instytucji cenzury (1990-2000), pod red. J. Adamowskiego, Warszawa 2000; M. Grabowska, Kultura w procesie transformacji systemowej, w: Barometr kultury, pod red. M. Grabowskiej, Warszawa 1992.

3 Por. R. Kowalczyk, Prasa lokalna w systemie komunikowania społecznego, Poznań 2003, s. 131-153. 
1) polityczno-ustrojowe (hegemonizm polityczny, redukujący w zasadzie do zera możliwości powstawania i funkcjonowania prasy niezależnej od państwa i aparatu polityczno-biurokratycznego),

2) prawne (wyrażające się istnieniem cenzury prewencyjnej i systemu innych ograniczeń prawnych, które uniemożliwiały materializację idei wolności słowa).

W rezultacie ich oddziaływania większość mieszkańców była pozbawiona dostępu do prasy lokalnej i tym samym do względnie aktualnych i wiarygodnych informacji dotyczących ich otoczenia. Okoliczności te sprzyjały petryfikacji układów lokalnych, które pozbawione kontroli i krytyki ze strony niezależnej prasy dominowały w systemie społeczno-politycznym i ekonomicznym miejscowych środowisk, ograniczając tym samym możliwości ich rozwoju.

Stadium popularyzacji wyrażało się umasowieniem produkcji i odbioru prasy lokalnej. Znikające bariery, ograniczające do tej pory rozwój niezależnych inicjatyw prasowo-wydawniczych, prowadziło do zwiększenia podaży i popytu na periodyki lokalne. W rezultacie prasa lokalna trafiała do najmniejszych siedzib i ośrodków, zaspokajając potrzeby i aspiracje miejscowych społeczności. Wraz z rozszerzaniem się jej wpływów wzrastały także siła i znaczenie prasy lokalnej w środowisku.

\section{Od popularyzacji do polaryzacji}

Wraz ze wzrostem popularności prasy lokalnej wzrastała także jej liczba. To zaś wzmagało konkurencję. W rezultacie prasa ulegała stopniowej komercjalizacji, a rynek prasowy polaryzował się. Istotny wpływ na ten proces miały różnice programowe istniejące między wydawnictwami, w tym poglądy polityczne nadawców i ich miejsce zajmowane w układzie lokalnym. Oddziaływanie tych czynników urozmaicało i uatrakcyjniało ogólną zawartość prasy lokalnej. Tym samym zwiększała się liczba krążących w społeczeństwie informacji oraz różnicował i powiększał się ich zakres. Proces ten w ostateczności prowadził do specjalizacji tematycznej i terytorialnej prasy lokalnej.

\section{Od polaryzacji do specjalizacji}

Stadium specjalizacji prasy jest objawem wyraźnych podziałów do jakich dochodzi wśród jej wydawców i odbiorców. Podziały te mają charak- 
ter tematyczny i terytorialny. Dotyczą więc zawartości prasy i zasięgu jej kolportażu.

W konsekwencji doszło do powstania dwóch charakterystycznych rodzajów prasy lokalnej: ogólnoinformacyjnej oraz periodyków środowiskowych. Te pierwsze są skierowane do wszystkich mieszkańców i stanowią swego rodzaju przegląd wydarzeń zachodzących w miejscowym środowisku. Te drugie zaś są adresowane głównie do wyodrębnionej kategorii czytelników, zainteresowanych konkretną tematyką.

W ostateczności specjalizacja terytorialna prasy prowadziła do zaspokajania ogólnoinformacyjnych potrzeb określonych społeczności, a cechą charakterystyczną jej zawartości jest homogeniczność i politematyczność. Natomiast specjalizacja tematyczna prasy jest odpowiedzią wydawców na indywidualne potrzeby wyodrębnionych grup odbiorców o określonych zainteresowaniach. Pisma takie są więc monotematyczne. W ten sposób dochodzimy do określenia charakteru i celu prasy lokalnej.

\section{Charakter i cele prasy lokalnej}

W zawartości ogólnoinformacyjnej prasy lokalnej dominują wiadomości skoncentrowane na jednostkowych, często losowych oraz konfrontacyjnych i negatywnych wydarzeniach o krótkiej żywotności. Natomiast zjawiska i procesy społeczne o złożonym charakterze i długotrwałym przebiegu praktycznie nie są w jej zawartości uwzględniane. Dzieje się tak dlatego, że dziennikarze skupiają się na tym, co jednostkowe i aktualne. W rezultacie, nie dostrzegając związków przyczynowo-skutkowych istniejących między określonymi zjawiskami, nie potrafią także zdefiniować i opisać określonego procesu społecznego, który składa się z sekwencji regularnie po sobie następujących faktów.

Charakter prasy lokalnej kształtował się pod wpływem oddziaływania dwóch ogólnych trendów. Jeden polegał na zawężaniu zakresu jej zainteresowania i zasięgu terytorialnego rozpowszechniania. Drugi zaś zasadzał się na jej tematycznym różnicowaniu się w ramach potrzeb zgłaszanych przez miejscowe środowiska.

W ten sposób dochodzimy do wniosku, iż celem czasopiśmiennictwa lokalnego jest zaspokajanie zróżnicowanych potrzeb informacyjnych i poznawczych odbiorców zamieszkujących niewielkie terytorium i skupiających uwagę na miejscowych wydarzeniach. Natomiast istotą prasy 
lokalnej jest w zasadzie integrowanie tego środowiska poprzez tworzenie określonej więzi mentalnej łączącej mieszkańców.

Z punktu widzenia interesu publicznego i misji prasy ważnym zadaniem periodyków lokalnych jest kształtowanie osobowości społecznej ludzi, a więc wpływanie na ich cechy psychiczne (pamięć, wolę, wyobraźnię, uczucia, inteligencję, spostrzeganie, temperament) oraz społeczne (przekazując wartości, normy i wzory społeczne oraz kształtując umiejętności wypełniania określonych ról społecznych ${ }^{4}$ ).

Przeobrażenia, jakim podlegała prasa lokalna prowadziły do tego, iż w niedługim czasie stała się ona jednym $\mathrm{z}$ ważnych elementów kultury masowej.

\section{Prasa lokalna elementem kultury masowej}

Za podstawową cechę kultury masowej uznaje się dążenie do prostoty treści i formy komunikatu oraz dostarczanie odbiorcom rozrywki ${ }^{5}$. Rezultatem tego procesu jest schematyzacja w przedstawianiu rzeczywistości. Dominuje prosty sposób objaśniania złożonych zjawisk i wydarzeń. Tak kształtuje się szablonowy język, wyrażający się narracją linearną i względnie logicznymi związkami przyczynowo-skutkowymi, co prowadzi do relatywnego zwiększenia komunikatywności przekazów, ale także do ich standaryzacji i homogenizacji. Ogranicza się w ten sposób udział w zawartości lokalnego piśmiennictwa innych bardziej złożonych form przekazu (na przykład felieton, reportaż, artykuł publicystyczny, dyskusja redakcyjna, komentarz do bieżących wydarzeń), które wymagają ze strony nadawcy większego wysiłku intelektualnego i często większych wydatków. Wypierają je więc proste w budowie oraz krótkie formy informacyjne (na przykład kalendaria wydarzeń, notatki, sprawozdania, wywiady). Lokalne wydawnictwa prasowe podlegając ogólnie znanym zasadom kultury masowej, stały się jej ważnym elementem, co ma istotny wpływ na definicję misji prasy lokalnej i sposób jej realizowania.

4 Według Jana Szczepańskiego rolą społeczną jest ,[...] względnie stały i wewnętrznie spójny system zachowań, będących reakcjami na zachowanie innych osób, przebiegających według mniej lub więcej ustalonego wzoru" (cyt. za R. Dyoniziak, J. Mikułowski Pomorski, Z. Pucek, Współczesne społeczeństwo polskie. Wstęp do socjologii, Warszawa 1974, s. 158).

5 Szerzej zob. A. Kłoskowska, Kultura masowa. Krytyka i obrona, Warszawa 1983; D. Strinati, Wprowadzenie do kultury popularnej, Poznań 1998. 


\section{Misja prasy lokalnej w społeczeństwie demokratycznym}

Misję prasy lokalnej możemy definiować przynajmniej w dwu perspektywach: realistycznej i idealistycznej.

Misją prasy - w jej ujęciu ściśle językowym - jest swego rodzaju posłannictwo. W ten sposób zakładamy, że musi istnieć osoba, grupa, społeczność, która powierza misję i obarcza prasę obowiązkiem jej realizacji. Pytamy wówczas także o warunki, w jakich dochodzi do sformułowania treści misji oraz o motywy, jakie stanęły u jej podstaw. Jeżeli założymy, że warunki ulegały zmianie, a wraz z nimi oczekiwania społeczeństwa i państwa, to zakres misji będzie również ulegał zmianie. To zaś oznacza, że treść misji ulega zmianie wraz ze zmianą społeczną. Zatem pojęcie misji należałoby definiować w kategoriach realistycznych.

Misja prasy definiowana w perspektywie idealistycznej oznacza przyjęcie za podstawę jej treści kategorie stałe, a nie elementy zmienne. W tym ujęciu misja prasy nie ulega zmianie wraz ze zmianą warunków społecznych. Będąc raz na zawsze sformułowana, jest jednocześnie pewnym modelem czy wzorem, do którego powinni nawiązywać wydawcy i dziennikarze.

Misję definiuje się często w kategoriach realistycznych i określa jako ważne zadanie do spełnienia. Misję się powierza lub zleca, co prowadzi zazwyczaj do wyodrębnienia jej źródła i depozytariusza, podmiotu i przedmiotu oraz zakresu.

Źródłem misji prasy są oczekiwania społeczeństwa, dla którego jest ona ważnym środkiem komunikowania i nie mniej ważnym elementem życia społecznego, politycznego, kulturowego. W jej działalności dostrzega się szczególną wartość. Wynika ona zarówno z funkcji spełnianej przez prasę w systemie demokratycznym, jak i jej znaczenia w nowoczesnym społeczeństwie. $\mathrm{W}$ ostateczności w pojęciu misji prasy wyraża się jej społeczna wartość. W związku z tym, że oczekiwania społeczne przyjmują w konsekwencji postać normatywną, dlatego misja prasy może być wyartykułowana jedynie przez prawo, za którym stoi instytucja państwa. W ten sposób staje się ono niejako depozytariuszem misji, która - wyrażając oczekiwania większości społeczeństwa - ma legitymizację zarówno państwa, jak i obywateli. Należy zauważyć, iż wola państwa w systemie demokratycznym jest zawsze w większym lub mniejszym stopniu wyrazem woli suwerena, którym jest naród.

W rezultacie działalność prasy, zaspokajającej określone potrzeby społeczne, stanowi wyraz woli państwa, które powierza temu podmiotowi 
konkretną misję do wypełnienia. Dlatego nadaje prasie określone prawa i wyznacza obowiązki. Państwo, gwarantując wolność prasy, nakłada na nią szereg odpowiedzialnych zadań, do których zalicza się w szczególności: 1) dostarczanie pełnej i prawdziwej informacji, 2) służenie jako forum wymiany komentarzy i krytyki, 3) wyrażanie pluralistycznej opinii publicznej, 4) przedstawianie reprezentatywnego obrazu rzeczywistości, 5) ukazywanie i wyjaśnianie celów i wartości społecznych, 6) zrównoważenie treści informacyjnych z rozrywkowymi, 7) dostarczanie informacji uwzględniających potrzeby i zainteresowania wszystkich grup społecznych ${ }^{6}$.

Podmiotem misji jest ten ośrodek, który ją praktycznie realizuje. A zatem jest nim prasa lokalna, czyli każdy konkretny wydawca, redaktor i dziennikarz. Misja prasy lokalnej jako środka komunikowania społecznego ma charakter publiczny. Można więc mówić również o jej funkcji publicznej. Posiłkując się pojęciem misji prasy, której źródłem w zasadzie jest społeczeństwo, jej podmiot określa swoje powinności wobec pewnej społeczności i precyzuje pojęcie misji w perspektywie partykularnej. W ten sposób dochodzi czasami do wypaczenia idei misji i jej zawężenia do potrzeb i interesów konkretnych nadawców. W rezultacie zindywidualizowane pojęcie misji prasy lokalnej może być między innymi wyrazem wyłącznie interesu nadawcy. Definiuje on wówczas swoją misję w kategoriach partykularnych - określając misję na przykład jako zarabianie pieniędzy. Chociaż tak wyrażona misja zazwyczaj nie jest werbalizowana, a zatem jest skrywana przed szerszą opinią publiczną. Misja prasy lokalnej nie musi być ujmowana w tak wąskiej perspektywie i może wyrażać interesy większej społeczności terytorialnej - misją prasy będzie wówczas na przykład stanowienie forum dialogu społecznego. Co jest najczęściej werbalizowane przez wielu nadawców i stanowi wyraz swego rodzaju obłudy istniejącej w życiu społeczno-politycznym, w którym to co istotne jest skrywane przed ogółem, a to co błahe dostępne dla wszystkich.

W możliwości formułowania misji prasy przez nią samą uwidacznia się często egoizm podmiotu, co w ostateczności może doprowadzić do złych skutków. Niezbędnym jest zatem istnienie pewnych norm prawnych (i możliwości ich egzekucji), które mogą im przeciwdziałać. Z drugiej jednak strony idea niezależności konkretnego podmiotu wydawniczego

6 Por. D. Piontek, Paradoks wolnych mediów, w: W kręgu mediów i polityki, pod red. D. Piontek, Wydawnictwo Naukowe INPiD UAM, Poznań 2003, s. 8. 
w formułowaniu swojej misji jest wyrazem wolności prasy. W rezultacie, każdy opowiadający się przeciw niezależności prasy występuje przeciw wolności prasy. Zważyć należy, iż swoisty egoizm prasowy nie może być zasadą organizującą jej funkcjonowanie. Społeczeństwo ma prawo do obrony przed taką postawą prasy, która uwzględniając tylko własny interes, marginalizuje interes społeczny, ogólny, publiczny.

Prasa, mając wpływ na kształt świadomości ludzi, nie jest tylko towarem na rynku. Jest ważnym środkiem oddziaływania społecznego. Nie może więc być uważana za taki sam produkt, jak każdy inny. Mimo, że działa na wolnym rynku dóbr i usług, gdzie zmaga się z konkurencją i walczy o odbiorcę, to jej właściwym rynkiem jest rynek informacji oraz idei i poglądów. Prasa ogólnoinformacyjna to w istocie forum, na którym powinny się ścierać różne opinie.

Przejdźmy zatem do określenia przedmiotu misji, co nie jest wcale takie łatwe. $\mathrm{Z}$ jednej bowiem strony bezspornym przedmiotem misji prasy są jej odbiorcy, na których ona ma się w ostateczności realizować. Z drugiej jednak bezpośrednim obiektem misji, jeżeli wolno tak powiedzieć, jest sama prasa widziana w perspektywie zarówno określonej struktury społecznej, składającej się z wydawców, redaktorów i dziennikarzy, jak również postrzegana jako strumień określonych przekazów generowanych przez tą strukturę.

W konsekwencji więc poza źródłem i depozytariuszem oraz podmiotem i przedmiotem misji, jako terminami odnoszącymi się do pewnych struktur społecznych, możemy mówić jeszcze o zakresie misji. Pojęcie to wyznacza granice misji i określa jej treść, która może:

Po pierwsze: składać się z terminów definiujących zachowanie się podmiotu misji wobec określonych struktur społecznych (na przykład: misją prasy jest kontrola władzy lokalnej) lub społeczności jako całości (na przykład: misją prasy jest dostarczanie czytelnikom informacji i poszerzanie ich wiedzy o środowisku);

Po drugie: wyrażać dążenie podmiotu misji do zmiany negatywnego stanu spraw publicznych (na przykład: misją prasy jest walka z korupcją);

Po trzecie: określać działania zmierzające do przeobrażenia świadomości ludzi (na przykład: misją prasy jest edukacja ekologiczna).

Kontrowersyjnym, lecz niezwykle ważnym zagadnieniem jest kontrola praktycznej realizacji misji prasy lokalnej. We współczesnym systemie prasowym kontrolę nad tym, czy konkretny podmiot wydawniczy dobrze wykonuje swoją misję sprawuje zazwyczaj on sam, ewentualnie sąd i opinia publiczna. W pierwszym wypadku prasa staje się sędzią w swojej spra- 
wie. Co z powodów zasadniczych nie może i nie powinno być akceptowane w demokratycznym społeczeństwie. W drugim niezawisły sąd rozstrzyga o tym, które normy prawa dotyczące głównie obowiązków prasy zostały złamane i dlaczego. W trzecim zaś opinia publiczna, formowana także przez prasę, artykułując interesy ogólnospołeczne sprawuje bezpośrednią społeczną kontrolę nad prasą. Jest to jednak w zasadzie kontrola iluzoryczna, która nie ma większego wpływu na sposób i formy realizacji misji prasy lokalnej. Dzieje się tak dlatego, że system społeczny generuje często sprzeczne opinie dotyczące misji prasy, a w szczególności jej zakresu, które w ostateczności znosząc się powodują, że żadna z nich nie uzyskuje poparcia większości. Ważnym w tych okolicznościach zagadnieniem jest określenie zadań prasy lokalnej. Czy polegają one na dostarczaniu informacji, czy objaśnianiu rzeczywistości?

\section{Dostarczanie informacji czy objaśnianie rzeczywistości}

W ustroju demokratycznym zakres praw, zadań i obowiązków prasy jest ogólnie określony przez prawo, istniejące w danym kraju. „Prasa, zgodnie z Konstytucją Rzeczypospolitej Polskiej, korzysta z wolności wypowiedzi i urzeczywistnia prawo obywateli do ich rzetelnego informowania, jawności życia publicznego oraz kontroli i krytyki społecznej” stwierdza prawo prasowe ${ }^{7}$. Podmiotem tych wolności oraz praw i obowiązków jest więc prasa w ogóle.

Zakres jej zadań zawiera się w dążeniu do wszechstronnego i rzetelnego zaspokajania potrzeb informacyjnych mieszkańców. Ponadto zalicza się do nich działania zmierzające do materializowania ważnych praw i wolności obywateli. Celem prasy jest więc zapewnienie większej jawności życia publicznego. A także sprawowanie społecznej kontroli nad działalnością określonych instytucji oraz zachowaniami i postawami ludzi. Jej ważnym uprawnieniem jest więc prawo do krytyki.

Na ogół podaje się, że celem ogólnoinformacyjnej prasy jest dostarczanie czytelnikom wiarygodnych, a zatem bezstronnych i obiektywnych informacji. Część wydawców prasy lokalnej uważa jednak, że ich powinnością wobec odbiorców jest nie tylko rozpowszechnianie rzetelnych informacji, ale również uczciwe, a więc niezależne komentowanie i wyja-

Zob. ustawa prawo prasowe z dnia 26 stycznia 1984 roku (Dz. U. 1984, Nr 5, poz. $24 \mathrm{z}$ późn. zm.). 
śnianie wydarzeń, umożliwiające czytelnikom dokładne poznanie rzeczywistości.

$\mathrm{Z}$ tego punktu widzenia zadaniem prasy lokalnej jest poszerzanie wiedzy odbiorców i rozwijanie ich ogólnych kompetencji społecznych, w szczególności dotyczących komunikowania. Taką praktykę nadawców można nazwać „służbą społeczną”. Jej celem jest głównie objaśnianie rzeczywistości poprzez dostarczanie czytelnikom wiarygodnych informacji, które poddane obiektywnej weryfikacji i ocenie mają przedstawiać prawdziwy obraz wydarzeń. W ten sposób dochodzimy do problematyki funkcji prasy lokalnej, która ma ważne znaczenie dla wyjaśnienia istoty misji tych wydawnictw.

\section{Nadawca w perspektywie funkcjonalnej}

Poszukując odpowiedzi na pytanie o misję prasy lokalnej, należy odwołać się do badań jej funkcji spełnianych w życiu społeczno-politycznym i ekonomicznym. W rezultacie próbuje się wówczas określić jej miejsce w złożonej siatce współzależności i układów łączących ją ze środowiskiem. Poprzez analizę funkcji prasy lokalnej odkrywamy jej rzeczywiste znaczenie w miejscowym systemie społecznym, politycznym, kulturowym i ekonomicznym ${ }^{8}$.

Nie ulega wątpliwości, iż zasadniczym celem prasy lokalnej jest systematyczne i efektywne zaspokajanie potrzeb informacyjnych miejscowego odbiorcy ${ }^{9}$. W ostateczności do jej podstawowych funkcji zalicza się w szczególności:

1) funkcję poznawczą, polegającą na dostarczaniu odbiorcom wiedzy o ich otoczeniu,

2) funkcję perswazyjną, zasadzającą się na kształtowaniu odpowiednich postaw wobec rzeczywistości,

3) funkcję motywacyjną, sprowadzającą się do pobudzania odbiorców do działania i aktywności poprzez dostarczanie im odpowiednich bodźców,

8 Szerzej na ten temat zob.: J. Szacki, Historia myśli socjologicznej, t. 2, Warszawa 1983, s. 783-815; Z. Oniszczuk, Pojęcie funkcji w badaniach nad społecznym oddziaływaniem prasy, „Zeszyty Prasoznawcze” 1988, nr 2.

9 Na temat funkcji prasy lokalnej zob. także: S. Dziki, W. Chorązki, Media lokalne i regionalne, w: Dziennikarstwo i świat mediów, pod red. Z. Bauera i E. Chudzińskiego, Kraków 2000, s. 130-131; R. Kowalczyk, Prasa lokalna w systemie komunikowania spolecznego, op. cit., s. 517-534. 
4) funkcję integracyjną, której zadaniem jest włączania ludzi w życie społeczne i skupianie ich uwagi wokół określonych problemów,

5) funkcję socjalizacyjną, odwołującą się do pozytywnych wartości i wzorów postępowania godnych naśladowania,

6) funkcję kontrolną, polegającą na sprawowaniu nadzoru nad różnymi przejawami życia społecznego, politycznego i gospodarczego,

7) funkcję rozrywkową, której celem jest dostarczanie przyjemności i relaksu.

Funkcje te wzajemnie się przenikają i uzupełniają. W rezultacie prasa lokalna nie tylko informuje o wydarzeniach i przeobrażeniach zachodzących w złożonej rzeczywistości, ale także uczy i wychowuje, kontroluje władze lokalne, przekonuje i motywuje, zachęca do działania, jednoczy lub dzieli ludzi oraz dostarcza rozrywki.

Swoisty funkcjonalizm prasy lokalnej jest uwarunkowany wieloma czynnikami, zarówno wewnętrznymi, jak i zewnętrznymi. Do czynników wewnętrznych zaliczymy wydawców i zespoły dziennikarsko-redakcyjne oraz standardy ich funkcjonowania. Zaś do czynników zewnętrznych w szczególności: 1) zorganizowanych i niezorganizowanych odbiorców prasy, 2) reklamodawców, 3) inne media, 4) instytucje samorządu gospodarczego oraz zawodowego dziennikarzy i wydawców prasy, 5) instytucje monitorujące działalność prasy, 6) instytucje państwowe, 7) instytucje samorządu terytorialnego, 8) instytucje gospodarcze, 9) instytucje społeczeństwa obywatelskiego, 10) instytucje religijne ${ }^{10}$. Przejdźmy zatem od funkcji prasy lokalnej do jej obowiązków.

\section{Obowiązki prasy}

Do zasadniczych obowiązków prasy należy prawdziwe przedstawianie omawianych zjawisk ${ }^{11}$. Dziennikarz ma więc rzetelnie opisywać oraz oceniać zjawiska, nie wypaczając ich przebiegu, znaczenia i roli. Zadaniem dziennikarza jest służba społeczeństwu i państwu ${ }^{12}$. Pojęcie „służby” kojarzy nam się przede wszystkim z obowiązkami nałożonymi przez prawo na odpowiednią instytucję i wyposażeniem jej w odpowiednie upraw-

10 Szerzej na ten temat zob. R. Kowalczyk, Prasa lokalna w systemie komunikowania spolecznego, op. cit., s. 401-406.

11 Zob. ustawa prawo prasowe, art. 6 ust. 1.

12 Ibidem, art. 10 ust. 1. 
nienia. W tym znaczeniu możemy określić prasę jako instytucję publicznej służby prasowej. Ale przecież służba jest również działaniem dla jakiejś idei czy poświęcanie się jakiejś sprawie. W ostateczności więc służba jest swego rodzaju odmianą misji albo formą jej realizacji, gdyż mówiąc o misji prasy, myślimy głównie o jej obowiązkach wobec czytelników.

Do podstawowych zadań dziennikarza należy sprawdzenie zgodności z prawdą uzyskanych informacji lub podanie ich źródła ${ }^{13}$. Powinien on chronić dobra osobiste bohaterów relacji prasowych, zarówno tych pozytywnych, jak negatywnych. A także dbać o interesy jego informatorów ${ }^{14}$, poprawność języka oraz unikać używania wulgaryzmów ${ }^{15}$. Obowiązkiem dziennikarza jest działanie zgodne z etyką zawodową i zasadami współżycia społecznego ${ }^{16}$.

W ten sposób zachowanie dziennikarza jest ograniczone nie tylko odpowiednimi przepisami prawa, lecz również pewnymi zasadami i normami postępowania obowiązującymi w danej społeczności. Zwyczaje społeczne, definiowane jako powszechnie przyjęty sposób postępowania, podlegająjednak ewolucji. A więc nie są stałe, lecz raczej dynamiczne. Ponadto dziennikarz jest zobowiązany $\mathrm{w}$ ramach stosunku pracy do realizowania ogólnej linii programowej redakcji, w której jest zatrudniony ${ }^{17}$. W praktyce prasy lokalnej zazwyczaj nie jest ona wyrażona expressis verbis, co znacznie komplikuje relacje zarówno wewnątrzredakcyjne, jak zewnętrz$n e^{18}$. Liczne obowiązki nałożone na dziennikarza tworzą w istocie gorset, który niekiedy utrudnia realizację jego głównej powinności, jaką jest dążenie do prawdy o rzeczywistości. Nawet wówczas, gdy jej obraz nie będzie korespondował z linią programową wydawnictwa. W ten sposób dochodzimy do problemu ograniczeń wolności prasy, jakie występują w jej zetknięciu się z rynkiem interesów i tworzą jednocześnie płaszczyznę przejawiania się jej interesu rynkowego.

13 Ibidem, art. 12 ust. 1 pkt 1.

14 Ibidem, pkt 2.

15 Ibidem, pkt 3.

16 Ibidem, art. 10 pkt 1.

17 Ibidem, pkt 2.

18 Szerzej na temat kontrowersji wokół problematyki „linii programowej” zob.: B. Michalski, Podstawowe problemy prawa prasowego, Warszawa 1998, s. 18-19; J. Sobczak, Prawo prasowe. Podręcznik akademicki, Warszawa 2000, s. 206-212. 


\section{Rynek interesów i interes rynkowy}

W rezultacie pojęcia misji i służby społecznej z perspektywy określonego podmiotu zawsze będą w mniejszym lub większym stopniu subiektywizowane, właściwie relatywizowane. Ich realizacja może przybierać różne formy, co jest uwarunkowane charakterem wydawnictwa i jego programem oraz typem własności i sytuacją, w jakiej aktualnie się znajduje nadawca i jego żywotne interesy. W konsekwencji dochodzi czasami do konfliktu między misją prasy, a wymogami konkurencyjnego rynku prasowo-wydawniczego. Z jednej strony mamy więc katalog formalnoprawnie określonych pryncypiów prasy, zawartych między innymi w Konstytucji RP i prawie prasowym. Z drugiej zaś realnie występujące zjawiska i procesy o charakterze wolnorynkowym, których wpływ na działalność prasy jest bezpośredni.

Posiłkując się wymogami rynku możemy podzielić prasę lokalną na podlegającą i nie podlegającą prawom podaży i popytu. Do pierwszej kategorii zaliczymy wydawnictwa komercyjne, których celem jest zarabianie pieniędzy. Ich dochód jest silnie powiązany z takimi kategoriami ekonomicznymi, jak wielkość sprzedaży egzemplarzowej i liczba płatnych ogłoszeń. Do drugiej kategorii włączymy pisma, których kondycja finansowa nie jest uzależniona bezpośrednio od sprzedaży egzemplarzowej i dochodów z reklamy. W ten sposób dochodzimy do wniosku, że prasa może być traktowana przez wydawców jako środek pomnażania kapitału finansowego lub narzędzie oddziaływania i wpływu społecznego. Często pełni ona podwójną rolę.

Jak więc widać celem działania prasy lokalnej może być zapewnienie zysku wydawcy, a nie realizacja misji, wyznaczonej jej przez prawo i oczekiwania społeczne. Z drugiej zaś strony może być ona wykorzystywana przez nadawców do rozpowszechniania informacji, których celem jest wywołanie odpowiednich reakcji odbiorców i skupienie ich uwagi na wybranych problemach. W ten sposób staje się narzędziem kształtowania świadomości ludzi w duchu partykularnych interesów i wartości bliskich nadawcy. W praktyce jednak - o czym wspominano - nie mamy do czynienia $\mathrm{z}$ typem idealnym, lecz $\mathrm{z}$ typem mieszanym, który stanowi próbę połączenia wartości finansowych i materialnych z duchowymi i niematerialnymi.

Często w wydawnictwach o charakterze komercyjnym mamy do czynienia $\mathrm{z}$ próbą znalezienia modus vivendi między wymogami rynku a misją prasy. Pojęcie modus vivendi oznacza także pewien szczególny 
sposób ułożenia relacji między nadawcą a odbiorcą. Są one oparte na tymczasowym kompromisie, który raz na zawsze nie rozstrzyga zasadniczych i spornych problemów. W ostateczności termin ten oddaje labilność owych stosunków, które wykazując się względną nietrwałością, mogą ulec zmianie i doprowadzić do częściowej lub zasadniczej modyfikacji zachowania nadawcy, co w konsekwencji skutkuje zmianą jego polityki informacyjnej.

\section{Polityka informacyjna nadawcy}

Analiza polityki informacyjnej umożliwia wyodrębnienie charakterystycznej dla każdego nadawcy praktyki komunikacyjnej. Można ją rozumieć w kategoriach sposobu, w jaki nadawca definiuje i opisuje rzeczywistość oraz ujmuje swoją w niej rolę. Jej wyrazem jest więc również określona postawa nadawcy wobec odbiorcy, która może przybrać postać: paternalistyczną, specjalizacji, profesjonalizacji lub rytualizacji. Polityka informacyjna nadawcy jest uzależniona głównie od formy własności prasy.

\section{A) Wlasnościowe determinanty polityki informacyjnej.}

1) Wydawnictwa o charakterze komercyjnym.

Pisma komercyjne, zabiegając o jak najliczniejszą grupę odbiorców, muszą systematycznie dostosowywać swoją ofertę do potrzeb i interesów heterogenicznego czytelnika. Ich polityka informacyjna jest w ostateczności uwarunkowana rodzajem prasy.

Komercyjne media popularne (najczęściej ogólnoinformacyjne tygodniki lokalne) zazwyczaj skupiają uwagę na informacji i rozrywce (co ilustruje homogeniczność ich zawartości). Następnie spełniają funkcję perswazyjną. Kolejność poszczególnych funkcji może się jednak zmieniać w zależności od aktualnych potrzeb czytelników i interesów wydawnictwa. Z czym mamy do czynienia zwłaszcza w czasie różnych kampanii społecznych i politycznych, wyborów, referendum, ważnych uroczystości, nieoczekiwanych zdarzeń oraz konfliktów.

W komercyjnych tytułach o charakterze specjalistycznym (najczęściej miesięczniki poświęcone kulturze, sztuce, hobby), które zwracają się do stosunkowo wąskiej kategorii adresatów, celem polityki informacyjnej jest zazwyczaj dostarczanie wiedzy. W następnej kolejności kształtowanie postaw, a na końcu dostarczanie rozrywki. 
2) Pisma o charakterze niekomercyjnym.

Wydawnictwa niekomercyjne stawiają przede wszystkim na cel informacyjno-perswazyjny lub perswazyjno-informacyjny, a na końcu rozrywkowy. Pismo ma głównie informować oraz zachęcać i przekonywać do czegoś lub kogoś, kreśląc pozytywny lub negatywny obraz konkretnych podmiotów. Zmieniać postawę i zachowanie odbiorcy. Wpływać na jego wiedzę i mobilizować do działania. Czasopisma niekomercyjne mogą też mieć inny układ celów swojej polityki informacyjnej. Na przykład przedkładać dostarczanie informacji nad oddziaływanie na czytelnika lub po prostu zapewniać mu rozrywkę. Kolejność poszczególnych celów może więc ulegać zmianie. Na ich porządek mają wpływ różne czynniki, zarówno wewnętrzne (wewnątrzwydawnicze i wewnątrzredakcyjne), jak i zewnętrzne (opinia publiczna, grupy nacisku, partie polityczne, organizacje pozarządowe, kościół, szkoła, władze lokalne).

W ostateczności charakter polityki informacyjnej jest determinowany określonym typem nadawcy (komercyjny, niekomercyjny), rodzajem prasy (tytuły specjalistyczne lub popularne) i programem wydawnictwa oraz jest uzależniony od wymagań środowiska. A zatem musi ona uwzględniać między innymi kompetencje komunikacyjne odbiorców.

b) polityka informacyjna a kompetencje komunikacyjne odbiorców

Wydawcy, przygotowując określone materiały prasowe i kierując je do zróżnicowanych kręgów odbiorczych, muszą dokonywać z jednej strony ich selekcji, według potrzeb oraz zainteresowań poszczególnych grup czytelników. $Z$ drugiej zaś powinni dostosować swoje wypowiedzi do ich możliwości percepcyjnych, czyli kompetencji komunikacyjnej. Warto więc zwrócić uwagę na dwa typy wiedzy, jaką muszą brać pod uwagę nadawcy. A mianowicie wiedzy potocznej i naukowej ${ }^{19}$, które przenikając się wpływają zarówno na zawartość, jak i odbiór zróżnicowanych komunikatów prasowych.

Wiedza potoczna to pewne uogólnienia dotyczące życia społeczno-politycznego i gospodarczego, tak zwana mądrość życiowa lub zdrowy rozsądek. Charakterystycznymi elementami tej wiedzy są między innymi

19 Jest to też dylemat wyrażany w zestawieniu „kultura wysoka - kultura niska”. Por. opinie N. Postmana, K. Popera, K. Jakubowicza w publikacji B. Ociepki, Dla kogo telewizja?, op. cit., s. 157-174. 
stereotypy, mity i przesądy, które upraszczając rzeczywistość czynią ją jednocześnie bardziej zrozumiałą dla przeciętnego odbiorcy i umożliwiają mu adaptację do nowych warunków oraz integrację z innymi członkami wspólnoty. Natomiast wiedza naukowa jest efektem systematycznej pracy badaczy i uczonych, którzy posługując się coraz doskonalszymi metodami i narzędziami odkrywają nowe związki oraz prawa i próbują na ich podstawie wyjaśniać różne aspekty złożonej rzeczywistości. Wiedzę taką cechuje rzetelność, obiektywizm i chęć rozwiązywania problemów ludzi i społeczeństwa.

Według Basila Bernsteina, który wyodrębnił kody ograniczony i rozbudowany ${ }^{20}$, jako sposoby definiujące możliwości komunikacyjne ludzi, większość osób dysponuje kodem ograniczonym i ma w istocie zawężoną kompetencję komunikacyjną. Jej charakterystyczną cechą jest przedkładanie relacji dosłownych nad abstrakcyjne. Zatem kod ograniczony z jednej strony ułatwia wymianę symboli stanowiących własność ogólną, z drugiej zaś utrudnia obieg symboli zindywidualizowanych.

Ogólnoinformacyjne media komercyjne, których przekazy są kierowane do heterogenicznej publiczności najczęściej ujmują rzeczywistość w perspektywie wiedzy potocznej, wykorzystując również elementy symboliki religijnej i narodowej. W ten sposób dostosowują się do możliwości statystycznego odbiorcy, który dysponuje ograniczoną kompetencją komunikacyjną.

W konsekwencji zrutynizowanego postępowania nadawców powstają standaryzowane komunikaty prasowe, które przedstawiają odbiorcom uproszczony obraz wydarzeń, zredukowanych do ich przeciętnych oczekiwań i możliwości percepcyjnych. Istotny wpływ na politykę informacyjną ma także zjawisko monopolizacji rynku prasowego.

c) monopolizacja rynku a polityka informacyjna.

Zdominowanie miejscowego rynku przez jeden podmiot prasowo-wydawniczy, co w niektórych środowiskach jest faktem, prowadzi do powstania swoistego monopolu informacyjnego i ograniczenia różnorodności opinii. W tych warunkach swobodny przepływ informacji ulega znacznemu ograniczeniu, co odbija się niekorzystnie na ilości i jakości krążących w społeczeństwie komunikatów. Proces selekcji materiałów typowanych

20 Por. B. Bernstein, Kod rozbudowany i kod ograniczony, w: Antropologia stowa. Zagadnienia i wybór tekstów, opr. G. Godlewski, A. Mencwel, R. Sulima, Warszawa 2003, s. $135-141$. 
do kolportażu jest w tych okolicznościach zdeterminowany interesami nadawcy, które w sytuacji braku konkurencji mogą spychać na dalszy plan interesy czytelnika.

W tych warunkach prasa staje się narzędziem, które jest wykorzystywane przez wydawcę zmierzającego do realizacji partykularnych interesów. W ten sposób nadawca nie musi się liczyć z opinią czytelników. Ci zaś nie mając innego wyboru i tak są zmuszeni do zakupu określonego pisma, by z niego czerpać podstawowe informacje o lokalnych wydarzeniach. W rezultacie prasa lokalna może opacznie przedstawiać to, co się dzieje w otoczeniu. Skutkiem są zdeformowane wydarzenia i niepełne relacje maskujące określone potrzeby i interesy wpływowych osób, grup, organizacji.

Opisując ten typ zachowania określonego wydawnictwa z powodzeniem można użyć pojęcia: kreowanie rzeczywistości. Jest to postępowanie, od którego bardzo blisko do uprawiania na łamach prasy swoistego makiawelizmu dziennikarskiego, nacechowanego przebiegłością, obłuda, przewrotnością, wyrachowaniem oraz brakiem skrupułów moralnych w dążeniu do osiagnnięcia zamierzonych, partykularnych celów.

W rezultacie polityka informacyjna wydawnictwa ma istotny wpływ na cechy przekazów prasowych.

\section{Cechy wspólczesnych przekazów prasowych}

Większe dochody z reklamy i ogłoszeń prowadzą do szybkiej komercjalizacji prasy lokalnej. Nadawcy w pogoni za zmniejszeniem kosztów produkcji i zwiększeniem zysku dążą do standaryzacji przekazu, nadając mu pożądaną przez potencjalnych odbiorców formę (często jednak zunifikowana). Podniesienie atrakcyjności prasy polega głównie na zamieszczaniu w niej komunikatów ekscytujących opinię publiczną, wpływających silnie na emocje czytelników, prostych i łatwych w odbiorze. Skutkiem takich zachowań nadawcy jest ograniczenie liczby poważnych przekazów, w miejsce których wchodzą proste i ogólnie zrozumiałe komunikaty. Coraz większą rolę w zawartości prasy lokalnej zaczynają odgrywać krótkie teksty informacyjne, rozrywka, sport, reklama i ogłoszenia. Zmniejsza to w oczywisty sposób liczbę materiałów publicystycznych, zwłaszcza o charakterze refleksyjnym i krytycznym ${ }^{21}$.

21 Por. R. Kowalczyk, Prasa lokalna $w$ województwie poznańskim $w$ latach 1989-1998, Poznań 1999, s. 14-30. 
Dążąc do uatrakcyjnienia komunikatów prasowych, ich nadawcy kierują się najczęściej zasadami: 1) nadzwyczajności, gdzie preferuje się materiały obalające ustalony porządek rzeczy, podważające status quo, pobudzające ciekawość czytelników; 2) ludzkich zainteresowań, gdzie pierwszeństwo mają teksty dotyczące życia osobistego człowieka, jego obyczajowości i intymności, w szczególności sceny z życia znanych ludzi.

Niektóre pisma, dążąc do wywołania sensacji, personalizują wydarzenia i polaryzują środowisko. W ten sposób często fałszują rzeczywistość i kreślą niespójny jej obraz, który wymyka się obiektywnym ocenom, podlegając jedynie ocenie emocjonalnej.

Charakterystyczną cechą ich zachowań jest bierność i stronienie od polemik z podmiotami miejscowych konfliktów oraz adwersarzami prezentowanej przez prasę postawy. Pisma takie nie stawiają trudnych pytań i zazwyczaj nie komentują wydarzeń. Nie zajmują się złożonymi problemami, bo są one często zbyt niebezpieczne. Poprzestają więc na powierzchownych relacjach z życia społecznego, politycznego i gospodarczego, rezygnując $z$ dochodzenia do obiektywnej prawdy o rzeczywistości. W rezultacie znacznie upraszczają świat nas otaczający. Jego obraz jest niepełny, spolaryzowany, sfragmentaryzowany, niereprezentatywny, niespójny i często nielogiczny. W zalewie informacyjnym odbiorca czuje się zagubiony, a media stają się ostateczną wyrocznią przesadzającą o tym, co jest lub nie jest prawdą czy fałszem.

Jednym z głównych celów tytułów ogólnoinformacyjnych jest dostarczanie odbiorcom wiedzy o otaczającej rzeczywistości. Nie jest to jednak wiedza szczegółowa, nie ma również charakteru systematycznego i zazwyczaj nie cechuje się refleksyjnością. Jest raczej skoncentrowana na wydarzeniach bieżących, wśród których dominują sensacyjne i spersonalizowane doniesienia oraz informacje dotyczące bieżącej działalności różnych instytucji życia publicznego ${ }^{22}$.

Każdy system społeczny w pewnym stopniu upraszcza i redukuje rzeczywistość, czego wyrazem jest między innymi jej schematyzacja. Nadawcy, zwiększając swoje możliwości produkcyjne, wykorzystują szablon i rutynę. Zachowania te prowadzą do standaryzacji przekazów, czyli ich ujednolicenia. W rezultacie tak skonstruowane komunikaty prasowe po-

22 Zob. R. Kowalczyk, Media lokalne i społeczeństwo. Wybrane zagadnienia na przyktadzie prasy lokalnej w Wielkopolsce, Poznań 2003, s. 189-204. 
mijają wpływ złożonych i zmiennych okoliczności, jakie towarzyszą każdemu zdarzeniu, i w ten sposób wypaczają niektóre związki łączące je z innymi faktami, zjawiskami, tendencjami. Ten sposób ukształtowania relacji prasowej prowadzi jednak do tego, że staje się ona zrozumiała dla przeciętnego czytelnika, oczekującego prostych rozwiązań złożonych problemów. Następstwem takiego zachowania nadawców i oczekiwań statystycznego odbiorcy jest kreowanie rzeczywistości, a niekiedy nawet manipulowanie nią. Co już nie jest przedmiotem mojego zainteresowania.

\section{Zakończenie}

Nie ulega wątpliwości, że misja i rynek to czynniki posiadające istotny wpływ na treść i formę przekazów oraz sposób funkcjonowania prasy. Zakres i siła tego wpływu są nie tylko zróżnicowane, ale także wielostronnie uwarunkowane, zarówno czynnikami wewnętrznymi, jak zewnętrznymi.

Misja i rynek to kategorie, które w odmienny sposób oddziałują na zakres obowiązków prasy lokalnej. Misja domaga się od niej spełniania celów ogólnospołecznych. Natomiast rynek zachęca do realizacji zadań komercyjnych i partykularnych. W rezultacie dla prasy lokalnej o charakterze komercyjnym to rynek jest najczęściej głównym czynnikiem wpływu, determinującym zarówno zakres jej zainteresowań, jak i sposób działania. Zaś prasa niekomercyjna, luźno powiązana z rynkiem, może w większym stopniu spełniać zadania misyjne. Chociaż tak być wcale nie musi, o czym świadczy jej wikłanie się w rozgrywki polityczne i czynne uczestnictwo w artykulacji partykularnych interesów jednostek, grup społecznych, partii i władz lokalnych.

\section{Summary}

The paper deals with the relation between the mission of local press and the market where this press operates and functions. This relation sometimes results in social tensions, or even conflicts. It should be borne in mind that the expectations of the market may have influence on the notion of mission and vice versa. It is important to answer the following question in this context: What is the influence these factors exert on local press? The mission and market are two categories that have a very different influence on the responsibilities of local press. The mission calls for general social objectives to be fulfilled. The market on the other hand encourages commercial and individual tasks. 